\title{
The nature of food \\ Indigenous Dene foodways and ontologies in the era of climate change
}

\author{
DAVID S. WALSH
}

limate change leading to a drastic decline in caribou populations has prompted strict hunting regulations in Canada's Northwest Territories since 2010. The Dene, a subarctic indigenous people, have responded by turning to tradition and calling for more respectful hunting to demonstrate respectful reciprocity to the caribou, including a community-driven foodways project on caribou conservation and Dene caribou conservation which I co-facilitated in 2011. In these ways the caribou is approached as a person. Dene responses to caribou decline can best be understood by ontological theories of an expanded notion of indigenous personhood. However, I argue these theories are inadequate without an attention to foodways, specifically the getting, sharing, and returning of food to the land. The necessity of sustenance reveals a complicated relationship of give-and-take between humans and caribou, negotiated by tradition, yet complicated by the contemporary crisis.

The Tłicho (pronounced clinchon) Dene, an indigenous people of subarctic Canada, rely on caribou for sustenance and identity as their ancestors did and caribou continue to provide their primary environmental relationship. ${ }^{1}$ The reliance on caribou culminates in a complex relationship of give and take;

1 Dene gatherings begin and end with a saying of masì, or thank you. I begin this article by saying masì to my Tlich consultants, mentors, and friends who shared their food, homes, and lives with me, and to whom I am deeply indebted. I would like to thank the Tlicho Nation for accommodating my research interests, and the RaeEdzo Friendship Centre and Allice Legat for inviting my participation in a number of community projects. The Canada Fulbright Program and Arizona State University Graduate College supplied funds to make my research possible, and this article has benefited from the guidance of Jenée Walsh, Miguel Astor-Aguilera, Beverly Lucas, Aldea Mulhern, and Eric Shuck. I would also like to express my gratitude to the Donner Institute for hosting the symposium on Religion and Food that would lead to this publication. As I reflect on relationships as paramount to my subject, it seems appropriate to maintain some of the original style of the talk, to honour the symposium and reflect the specific place and context that allowed my work to grow into this article. 
the Dene must demonstrate respectful reciprocity so that the caribou will give their flesh to hunters. Climate change has caused a rapid decline in caribou populations since 2009 (Adamczewski et al. 2009), straining this relationship. Tłicho Dene elders with whom I work draw from larger Dene ontologies in responding to the caribou decline with the imperative to respect the caribou, a perspective that conflicts with the Canadian ecological perspective. While the Canadian government and wildlife biologists have implemented strict hunting restrictions to protect caribou, Tłicho Dene elders suggest respectful hunting

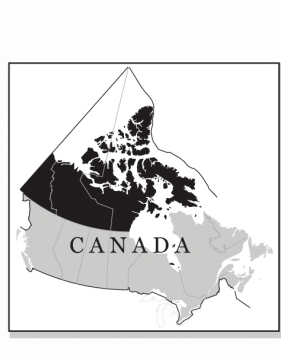

\section{http://atlas.gc.ca}

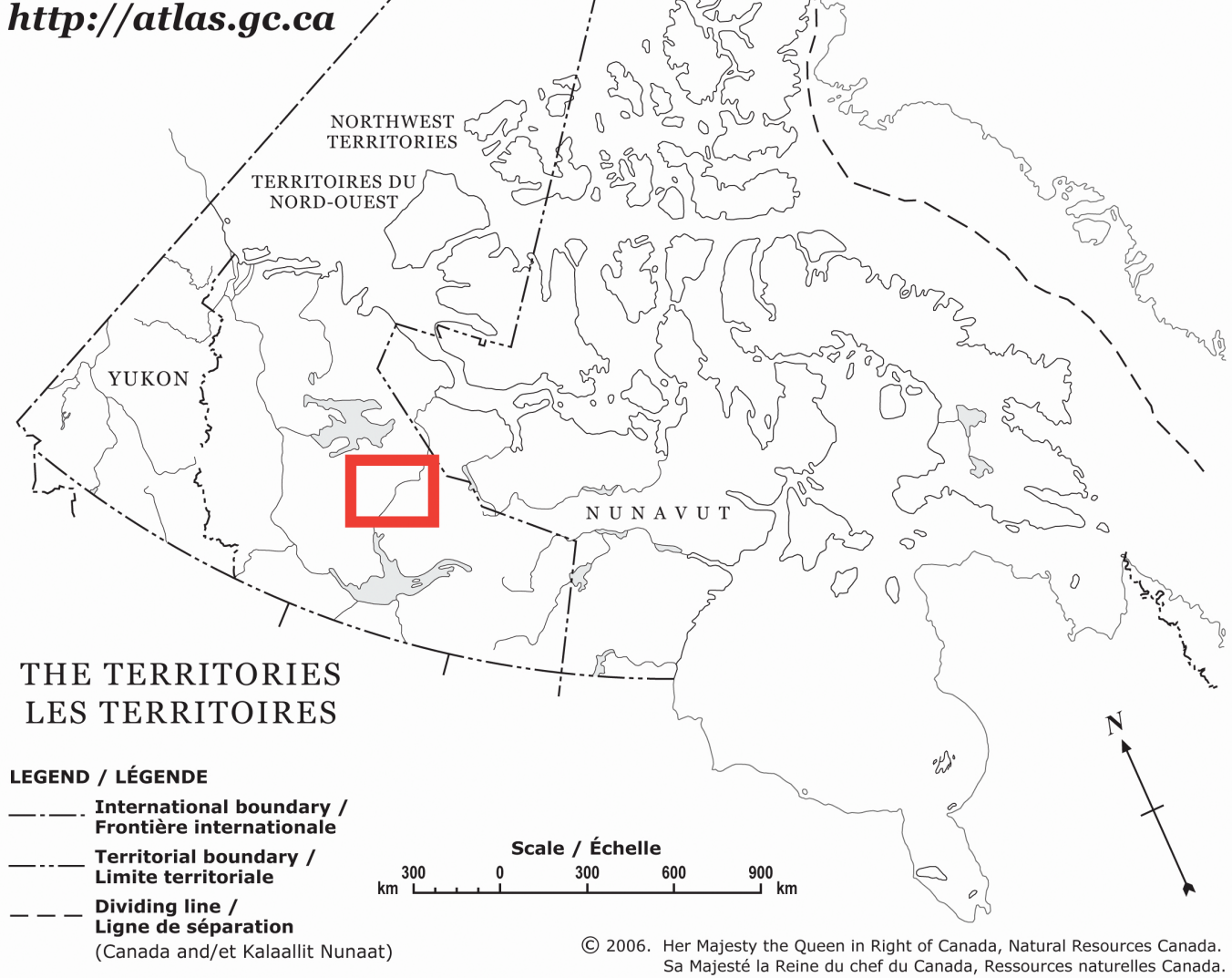


practices are necessary to convince the caribou they are still needed and will return to the people.

Indigenous peoples' relationships to their environment have preoccupied scholars since E. B. Tylor ( 87 I: 427) introduced a theory of animism which displaced indigenous religions from the living environment to the realm of spirits. Tylor assumed a Cartesian dichotomy of nature and culture which contemporary scholarship (e.g. Descola I996, Ingold 2000, Viveiros de Castro I 998) contends is not applicable to indigenous ontologies of the Americas and the Circumpolar North, instead positing relational ontologies wherein indigenous peoples engage directly with and within their environment. Scholarship (e.g. Astor-Aguilera 2010, Detwiler 1992, Harvey 2005, Morrison 2002, Shorter 2009) on indigenous North American religions corrects Tylor's (ibid.) abstractions by re-placing beings in the environment through an expanded notion of personhood; that indigenous persons can engage beings in the environment, such as animals, plants, rocks, wind, spirits, and ancestors, as non-human persons. Indigenous religious traditions of the Americas are defined by their relationships with social beings in the living environment.

I examine Dene environmental relationships through the lens of food, and specifically what I identify as three stages of Dene foodways: getting food, sharing food, and returning food and remains back to the land. Food is integral to many studies of indigenous religions and environmental relations (e.g. Gill I 982, Grim 2001, Holst I 997, Nabokov 2007). However, how a dependence on the environment for food affects social dynamics that include non-humans has not been addressed (with a few notable exceptions, including Crawford O'Brien 2014, Swanson 2009). Analysis through the foodways stages reveals complex social relationships between hunters, food-animals, and beings who aid in the exchange, such as ancestors and the land itself. These relationships complicate previous scholarship, including by revealing patriarchal biases in this scholarship. In this way, foodways as a component to theories of personhood explains Dene attitudes toward caribou, and offers insight into the relationships of other indigenous nations and their food sources. My aim is to demonstrate how foodways, as an analytical category, offers a glimpse within Dene paradigms to perceive non-human entities as something with which humans relate, while simultaneously demonstrating through foodways the limits of the relationships and complicating previous theories of indigenous religion and personhood. An attention to foodways reveals the necessity of sustenance as a primary motivation for indigenous relationships to other beings. Sustenance offers an entry point for understanding the relational ontologies of indigenous peoples, exemplified specifically by the Tłicho Dene. 


\section{Contemporary threats to the caribou}

The Tticho Dene live in their ancestral homeland north of Yellowknife and Great Slave Lake, and south of Great Bear Lake, in the Northwest Territories, Canada. Hunter-gatherers, the the Dene emphasize hunting as wild crops are less abundant in the north: they hunt big game like caribou and moose; and small game that is trapped, including rabbit, muskrat, beaver; ducks and geese; and lots of fish. The Tłicho were in an isolated pocket, without contact with Europeans, longer than any other indigenous people in North America (Helm 2000). They first met Catholic Oblate missionaries from France and Belgium in the I86os. Even after contact, the Tiicho maintained nomadic lifestyles of trapping, fishing, and following migrating game for another hundred years until the Canadian government established settled communities in the r96os. Most Dene peoples still maintain hunting and fishing subsistence lifestyles. The Tłicho in particular maintain diets high in traditional food, but this is changing between generations (Tlicho 20I2). I have sat at meals where elders in the house eat only caribou, moose, and fish, while the youth eat store-bought meats and processed foods.

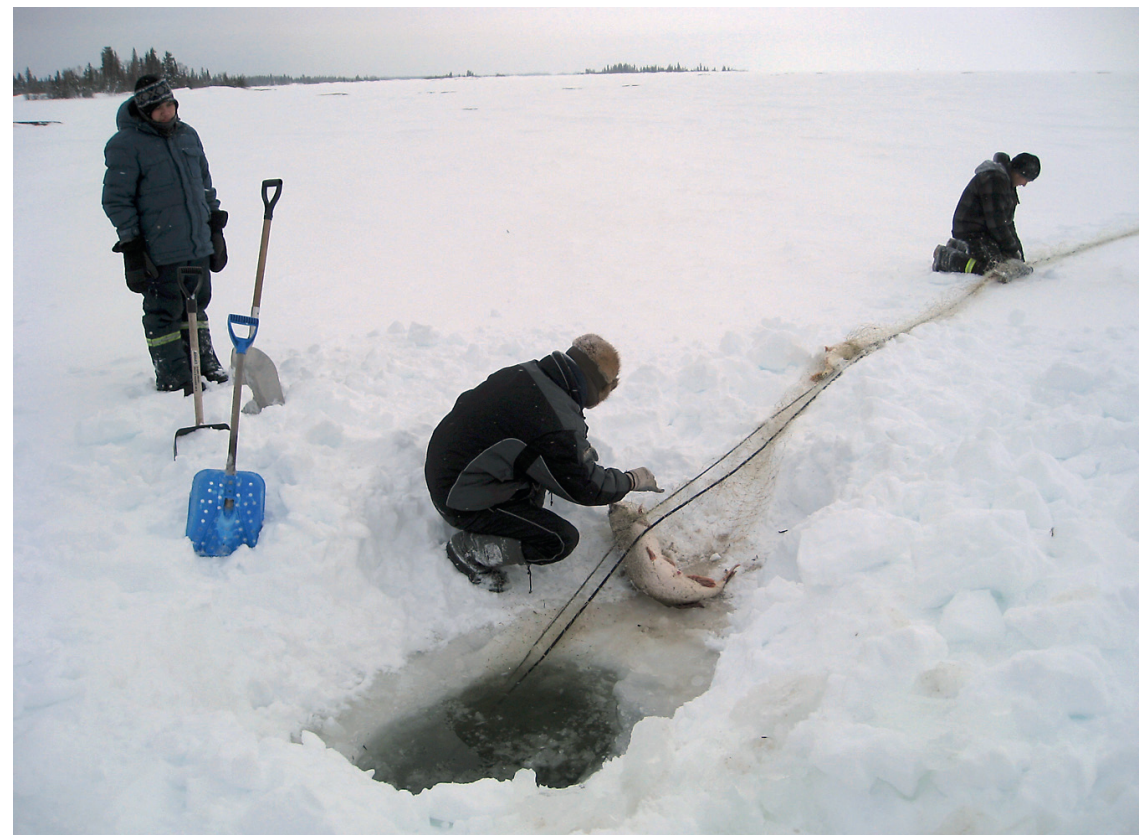

An elder demonstrates how to check the fish net on Great Slave Lake, Northwest Territories, Canada. Photograph by David S. Walsh. 
The Tłicho belong to the Athapaskan linguistic family. Athapaskans spread across northwestern Canada into Alaska, with a few pockets in Oregon and northern California, and include the larger Navajo and Apache Nations in the south-western United States. Athapaskans of eastern Alaska, the Northwest Territories, Yukon, northern Alberta, and British Columbia, are commonly referred to as a whole as the Dene, of which the Tticho are one nation (Abel 2005).

The present day Tłichę territory consists of 39,400 square kilometres of land, effective since their land claim with the Canadian government in 2005 (see Tficho 2005). Unlike reservations in the United States and southern Canada, they are a self-governed nation-within-a-nation. There are four Tficho communities. The three smaller and more remote are: Whatì in the west, Gamètì to the north, and Wekweètì to the far east; the fourth and largest community is Behchokò. The remote communities are only accessible by plane, by a gruelling boat trip with portages, or via ice roads open for a few months during winter, though Behchokò as the Ttichọ capital maintains year-round highway access. The population of the four communities is approximately 3,000 Tlicho citizens (NWT 2013), leaving a vast open land on the edge of the taiga and the beginning of the arctic tundra, consisting of muskeg, permafrost, marsh, forest, and exposed Canadian Shield bedrock.

For the Tlicho, caribou are of prime cultural significance. There are two caribou herds that routinely migrate to Tticho lands and are hunted during fall and late winter/early spring: the Bathurst and the Bluenose East. The Bathurst is the primary herd for Tłicho hunters, while the Bluenose East generally travels north of Gamètì, around the Great Bear Lake. Caribou, and their domesticated cousins the reindeer, have cultural significance for indigenous peoples across the Circumpolar North. These and other similarities led Åke Hultkrantz ( $994: 354$ ) to define a 'circumpolar religion' as constituted by a 'relative lack of elaborate ceremonies and the intense concentration of religious activities on daily sustenance and protection from a harsh environment.' Yet he states that religion focused on sustenance 'should not be taken as indicative of a low level of spirituality' (ibid.). The Dene exemplify a practical, lived, embodied, but nonceremonial spiritual life focused on survival. Maintaining proper relations with the caribou is paramount to this survival. Thus, studies of Dene religion must take into account the necessity of sustenance, or risk reifying Western categories of the religious.

In stark contrast to Dene worldviews, the Department of the Environment and Natural Resources for the Northwest Territories proposed a complete hunting ban on the Bathurst and Bluenose East herds, citing an accelerated 
rate of decline for the Bathurst herd from 475,000 animals in the I 980 s to just 32,000 in 2009; a 93 per cent decrease (Adamczewski et al. 2009). With a combined annual aboriginal, sport, and Northwest Territories non-aboriginal resident harvest of 7,000 caribou, the herd was estimated to become extinct in four years, by 20I4. Environment and Natural Resources acknowledged the cultural importance of caribou for all northern residents, and worked with aboriginal governments to negotiate solutions. After much public debate the ban was negotiated to stay in effect for all non-aboriginal and sport hunters, but eased to a limited tag system for the Tłicho and neighbouring Yellowknives Dene to 300 animals annually; not enough to maintain a traditional subsistence lifestyle for the Tłicho and Yellowknives Dene populations. The more isolated Bluenose East herd would remain open for indigenous harvests, an option only for those who could afford the extra time and financial commitment needed for the trip.

Climate change is the predominant reason for the declining caribou populations: hotter-than-average summers and colder, drier winters led to an increase in forest fires and a decrease in lichen, the primary food source for caribou (Adamczewski et al. 2009: 3; Gunn 2007: 3-5). Additionally, there is a heated debate on the impact of over-hunting. In the two winters before the imposition of the 20 Io hunting ban, caribou migrated directly onto the ice road near Behchokò and the highway to Yellowknife, allowing hunters from all over the territories and Alberta unprecedented access to the animals. Rather than needing to snowmobile to find the herd, camp, pack the meat and transport it back, hunters were simply hunting from their trucks and throwing the meat in the back. The influx of hunters and ease of access allowed some to take advantage; many took only choice cuts of meat and left unused carcasses, having a detrimental effect on an already declining caribou herd. While the Environment and Natural Resources Department determined that climate change was the main culprit against caribou viability, they suggested hunting must be curtailed to prevent extinction. This viewpoint reflects a Western ecological ontology wherein nature is either dominated or managed (Nadasdy 20II). In this case wildlife is managed through a stewardship model of protection that denies an agency to the caribou over its own viability and relationships with humans.

Similarly to the Environment and Natural Resources Department, the Tłicho Dene addressed hunting practices as the solution to caribou decline. However, they arrived at an opposite conclusion. Dene elders spoke of the need for more respectful hunting practices in order to demonstrate their continued need and love for the caribou, who would respond in kind by returning to the Tłicho (Drybones and Walsh 20II). Dene responses to climate change and how they fundamentally differ from those of the Canadian government and 
scientists are understood through theories of indigenous ontologies and personhood. These theories are inadequate without an attention to the specific foodways contexts of a people. I turn now to the context of Dene foodways.

\section{Indigenous ontologies and personhood}

Indigenous peoples of the Americas retain ontological similarities despite rich historical and cultural diversity (see Astor-Aguilera 2010: 197, 213; Crawford O'Brien 2014). A resurgence of scholarship addressing indigenous ontologies as distinct from Western ontologies is increasingly referred to as the 'ontological turn'. Scholars leading the ontological turn in anthropology (Descola I 996, Ingold 2000, Latour I 993, Viveiros de Castro I 998), and scholars of indigenous religious traditions (e.g. Astor-Aguilera 20 Io, Detwiler I 992, Harvey 2005, Morrison 2002, Shorter 2009) demonstrate that indigenous ontologies are relational. ${ }^{2}$ Indigenous ontologies are predicated on a relatable world wherein indigenous peoples directly engage with the environment and living beings within the environment, thus avoiding the Cartesian dichotomy of nature and culture prevalent in modern Western worldviews. Kenneth M. Morrison (2002: 39) states that the parallel Cartesian dichotomy of natural and supernatural is also non-applicable to indigenous religious traditions. Henry S. Sharp (200 : 67) states, in regards to the Dene specifically, that what Westerners might consider supernatural exists in the natural realm as an integrated whole. I suggest that nature, culture, and the supernatural do not comprise a trichotomy in Dene ontologies, nor are they an integrated whole per Sharp, but that the categories of nature, culture, and the supernatural simply do not exist in Dene ontologies. Thus, the religious is of this world and can be held in social relationships: animals, ancestors, and spirits are social beings with whom the living engage for the benefit of humanity.

Many of the above scholars draw from A. Irving Hallowell (i 967 [I 955], I 975 [I960]) in referring to all beings in indigenous contexts as 'persons.' Hallowell states that the Ojibwa of Canada lack a nature/culture dichotomy, and that their behavioural environment is comprised of beings possessing agency, power, and the ability to communicate. Thus, these beings can have relationships with human beings. Hallowell (I975 [I960]: I44) states that 'persons as a class

2 I include Bruno Latour (I 993) here, although he does not discuss indigenous ontologies, as his critique of Cartesian dualisms is informative to the emerging ontological turn. 
include entities other than human beings', Beings such as animals, plants, rocks, land, bodies of water, and the elements, are not automatons nor abstract spirits; they are tangible beings with whom humans interact (see also Walsh 20I I). Hallowell (ibid.) refers to non-human beings with whom human beings relate as 'other-than-human-beings' and 'other-than-human-persons' as they carry the same traits as persons and can be engaged as persons, yet are not human.

Morrison (2002: 40) builds on Hallowell's other-than-human-persons, stating that the Ojibwa live in a cosmos constituted by persons, and thus think in relational rather than objective terms. Animals are not beings to be studied and used indiscriminately, but are to be related to as persons, and in fact must be related to if one wishes to survive. Relation must become relationship. Humans and animals are not automatically connected, but must work at the connection as one would with a friend, relative, or partner. An expanded notion of personhood suggests that indigenous peoples of the Americas engage animals and other beings in the environment as persons with whom human persons can form reciprocal relationships.

Graham Harvey (2005, 2010), who delivered a keynote paper at the Donner Symposium on Religion and Food, derives from Hallowell's theory of otherthan-human-persons, that all embodied beings, whether human, animal, rock, wind, spirits, etcetera, may carry the traits of personhood. Personhood does not rely solely on an embodied existence, but is relational and derives from the relationships between beings. The Dene are human persons who dine on caribou persons, as vegetarians dine on vegetable persons. The Dene also eat vegetables, but as imported foods these do not carry the same ontological significance as caribou. This is not to say that vegetable beings could not be persons, but that they do not share a personal history with the Dene, and as they are imported they do not require reciprocity to be harvested.

Harvey (2005, 2010) asserts that the personhood of beings is a defining feature of animism. He draws from Tylor's ( 187 r: 427) definition of animism as a belief that souls and spirits exist, yet Harvey grounds the term in the notion that the environment is animate. Harvey (2005: 6) notes that Tylor derived his conception of animism from the specific context of indigenous peoples' relationship to the environment, erring when he universalized animism as the foundation of all religion. Tylor ( 87 r : 445) stated that some animists did not make a distinction between nature and culture, a vastly important insight that became lost in the work of his successors. Harvey (2010) offers a new definition of animism that does not abstract to the realm of spirits, but places animism in the very being of animals, plants, etcetera, with whom animists have reciprocal relationships. 
The manner in which some Dene approach the caribou would seem to exemplify Harvey's animism, yet further analysis reveals both a limit to personhood theory and fundamental differences between Dene persons and caribou persons. Harvey focuses on similarities between persons, such as what relates a human person to a caribou person. But this relation raises a fundamental question: if animists are persons and caribou are persons, how can the animist eat the caribou? Harvey (2005: 163 ) is one of the few scholars discussing personhood who raises the issue of food and the necessity of eating others. He asks whether a human person eating an animal person constitutes cannibalism. The Dene are decidedly not cannibals. Emile Petitot (2005: 197) related from his I 86os-80s missionary travels that the Dene regarded stories of Cree cannibalism with horror. Morrison (2002: 64) states that cannibalism is accounted for in indigenous Algonkian worldviews as inter-species but perhaps not interpersonal eating, stating that cannibals were antisocial beings incapable of a relationship with persons. Harvey concludes that eating non-human persons is not cannibalism by arguing that if everyone is a person, not everyone is kin, not everyone is enemy, and not everyone is food. But some are'. The connections between people are unique to each relationship and as per Harvey's example, some are based on the necessity of sustenance, yet the question remains, how can one person eat another person? ${ }^{3}$

I suggest to relate is to connect. While connection suggests the overcoming of difference, the difference itself is necessary, lest one become the other. Connecting is a negotiation of this line, of relying on others while maintaining difference, and that is apparent in the way the Dene discuss hunting restrictions. They recognize a deep historical and personal connection with the caribou, but they also recognize that the caribou are different from human persons. This is where I depart from Hallowell (I967 [1955], I975 [1960]), Morrison (2002), and Harvey (2005, 2010). They, and most scholarship on indigenous personhood, focus on a shared personhood that does not adequately take into account difference, and interestingly does not pay attention to gender difference and gendering within the personhood of beings. An attention to the necessity of eating the other, however, reveals that a fundamental difference must be maintained in order to avoid cannibalism. You are not what you eat. The contradiction of needing to strengthen connections between species to attain

3 Ultimately terms such as animism, cannibalism, and personhood are derived from Western philosophical traditions and may aid etic scholarship but should be taken with caution of their ability to represent emic worldviews. 
food, while maintaining difference in order to eat that food, demonstrates the nuances of Dene environmental relations between personhood and speciation. I turn now to examine Dene foodways as it relates to theories of ontology.

\section{Dene foodways}

Dene foodways traditions necessitate relations with the environment to provide sustenance. Scholars of religious studies (e.g. Eden 2008, Finch 2010, Fuller i 996, Madden and Finch 2006, Sack 2000, Zeller et al. 2014), following predominantly from anthropologists (e.g. Douglas i 966, Harris et al. 2005, Long 2004), approach foodways as a universal social force that concretizes group identities and spiritualities. Lucy M. Long (2004) defines foodways as the 'network of behaviors, traditions, and beliefs concerning food, and involves all the activities surrounding a food and its consumption, including the procurement, preservation, preparation, presentation, and performance of that food'. I add activities specific to Dene foodways to Long's definition. Prior to procurement, Dene foodways include dreaming of the animal and its location (Helm 2000: 273; Legat 201 2: 9I) as well as visiting ancestors' graves on the way to a hunt (Legat 201 2: 92). The use of of ik'ò or 'medicine power' may increase one's luck in hunting (Helm 2000: 273). In addition to Long's 'presentation and performance', I add sharing food within the community and food offerings made to ancestors. A final step is the proper disposal of remains in order to aid an animal's rebirth and continue the reciprocal cycle of gifting sustenance.

I delineate three stages of Dene foodways: getting, sharing, and returning food. In practice these stages overlap. Fresh food offerings to the fire after hunting bind the first and final stages, and a successful hunt is dependent on properly sharing meat and disposing of waste from previous hunts. Dividing foodways into three stages aids academic analysis, yet the lack of codified stages is informative for understanding Dene worldviews. The first European explorers of the Canadian North remarked that the Dene lacked any codified systems, proclaiming the Dene to lack religion or ritual (see Mason I 9 I 4: 376). Analysis through the three foodways stages brings to light a distinct spirituality that informs contemporary Tłicho Dene responses to the caribou decline.

\section{Getting food}

Paul Nadasdy (2003: I 24) states that hunting is more than the acts associated with killing an animal; that hunting is an entire complex of values, practices, and social relations that give meaning to indigenous relationships with 
animals. A successful hunt is not one in which the hunter stalks and overpowers an animal, but success comes when the hunter finds the animal that has gifted itself as food (Legat 201 2: 83). In Dene relationships with caribou, hunting is an exchange of respectful reciprocity between consenting beings: animals gift themselves to hunters; hunters reciprocate through proper treatment of the meat and remains, for which the animals are thankful and continue to give themselves. Reciprocation maintains balance within the relationship between hunter and hunted. Techniques of reciprocity are centred on the notion of offering respect. Specific animals are known to the Dene to find certain actions disrespectful. For instance, it is appropriate to kill many animals and fish by a quick hit over the head with a heavy stick, but one must not hit a caribou (Blondin 2006: I 68) or rabbit (Helm 2000: 59) or the animal will stop giving itself. Other actions are offensive to all animals as they disrespect the sacrifice of the animal, such as boasting of one's hunting abilities (Nelson I 983:23), stepping over spilt blood at a hunt site or home, women stepping over a hunter's rifle, especially when menstruating (Smith I 973: I3), and, as my consultants told me, bringing the meat or wearing the hide of another animal on a hunt.

Scholars (e.g. Helm 2000, Nelson I983, Ryan I995) discuss respectful actions in terms of mandated rules, laws, and taboos. However, I see interspecies social conventions as guiding personal relationships. Marie Francois Guédon (I 994: 42) states that prohibitions, specifically as pertaining to menstruation and her role as a female researcher, are not rules to be obeyed but, 'the expression of my personal relationship with streams, paths, door-steps, men, food, and even myself as a woman'. Rather than institutionalized sexism, prohibitions pertaining to women, as with other actions of respect and disrespect discussed above, are displays of etiquette: social norms of how to treat one another that transcend the boundaries of species. Breaking prohibitions is impolite because it demonstrates a lack of need for the animal being pursued. Wearing the hide of another animal on a caribou hunt, for example, demonstrates to the caribou that its gift may not be appreciated as the hunter flaunts their relationship with the other. Hunters need not reciprocate in all manners possible, but the importance of reciprocity and displays of etiquette are paramount during times of crisis, such as when the caribou do not return for their bi-annual migration.

Robin Ridington (1990: 85) states that reciprocity and demonstrations of respect are 'food-getting techniques and technologies', suggesting that other technologies, such as dreaming of an animal before a hunt, are as practical as modern technologies such as traps and rifles. Historically, a hunter or leader of a hunting party would dream of the specific individual caribou (Helm I 994: 77), who would tell the hunter where to find them on their migration (Jacobsen 
Commensality: sharing food

After the gift of an animal is received, preparing, cooking, and distributing food are also opportunities for demonstrating respect to the animal through sharing its meat. Ridington (I990: 88) states that meat is not the exclusive property of the hunter, but it is shared within the community out of an ethic of reciprocity that guides human relationships. There are no formal rules for sharing and distributing meat to family and to the community, nor do gifts demand a return. Rather, sharing is a social necessity (Nadasdy 2003: 73, see also Guédon I 974: 2 I 9; Simeone I 995: I 53-9). Human reciprocity is an obligation, 'that the animals insist on in order for them to continue to provide their gifts of life' (Smith 2002: 6I). Sharing between humans is necessary to ensure continued sharing with animals.

The influx of store-bought foods has changed subsistence lifestyles: community stores provide an ease to food acquisition, with detriments of economic dependence and negative health impacts associated with processed foods (Haman 2010). New food sources have not replaced traditional foods, as half of Tłicho citizens' diets still consist of traditional foods (Tłicho 20 1 2: 23). Through processes of naturalization new foods are integrated into Tłicho palates. The meat of foreign animals, boiled or prepared over a fire with added salt, is consistent with older tastes, and goods such as canned meat and fruit, bannock bread, and tea were readily accepted into pre-settlement lifestyles. Dietary changes reflect historical changes. However, these changes are absorbed within a continuity of worldviews and social paradigms.

New foods are shared in traditional ways, though it is more respectable and appreciated to share traditional foods like caribou or fish. When visiting elders I would bring a bag of oranges, a treat that prompted stories of the first time they were given an orange after a trading party returned from the Hudson Bay store at Fort Rae, Northwest Territories. I seldom entered a home without being offered something to eat: caribou, fish, moose, and most always bannock bread with butter, jam, and tea. Although there is a constant attention to food, eating is often conducted without fanfare. Meals are prepared for oneself at any time, and consumed quickly and without comment. Extra is made for others to help themselves, and there is not an emphasis on communal meal times. Feasts, however, are a different case.

Feasts are special moments of food exchange. Sometimes they are family affairs, associated with Catholic and state holidays. Other times feasts involve the larger community, such as those hosted by the community government for special occasions: the opening of the school year, or the anniversary of 
establishing self-government. While these are modern celebrations, they reflect traditions of feasts in the bush, and large gatherings at trading forts for treaty days (Helm 2000: 328). Historically there were great feasts, such as the several day celebration when Chief Edzo made peace with the Yellowknives Dene at Got'okati, Mesa Lake, in the I 820 (Helm and Gillespie I 98 I: I6). Nearly 200 years later the circle worn into the ground from joyous dancing can still be seen by hunters venturing to Gots'okati and the tundra in the fall. A third type of feast are those hosted by families that involve the larger community. Most common are wedding and funeral feasts, wherein everyone is welcome to attend, even if only to get a plate of food and take it home.

Traditional foods are served at most weddings, funerals, and community feasts, such as caribou and fish, along with naturalized foods that still appeal to elders such as bannock, oranges, hot dogs, hard boiled eggs, noodle salad with canned meat, a rice pudding called kwet'sa, canned fruit sometimes poured over $k$ wet'sa, and coffee and tea. Smaller family feasts may involve traditional and naturalized foods, and others more typical of southern Canadian tastes: baked ham or turkey, grilled hamburgers, mashed potatoes, beer, and if one is returning from the city of Yellowknife, Kentucky Fried Chicken. Andrews (201 I: 222 ) states that traditionally men served food to family members sitting on the

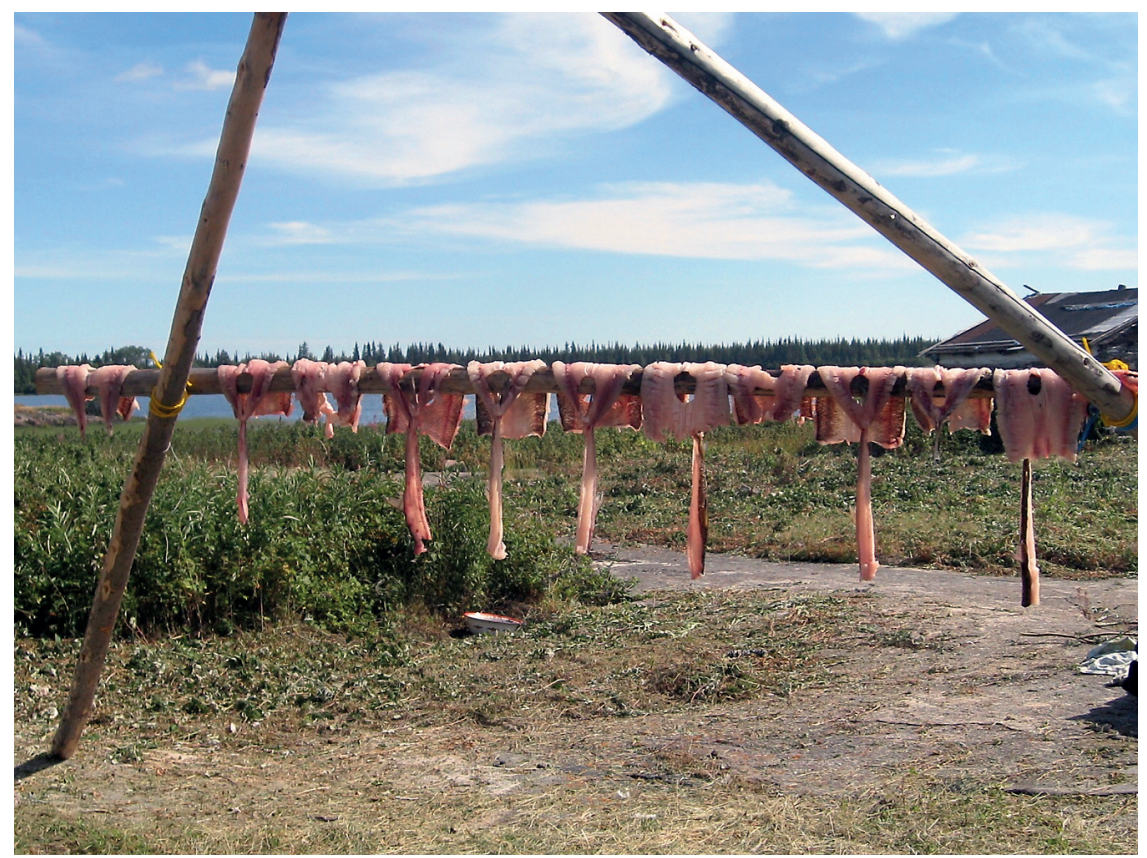

Making dried fish. Photograph by David S. Walsh. 
floor, a practice that has given way to the buffet, self-serve style. The funeral and wedding feasts I attended, however, were a mixture of served and self-serve styles. Men predominantly served, especially to important guests such as elders and Catholic priests. Larger community feasts begin with a prayer typically led by a male elder, although gender divisions are not strictly enforced and a female elder may lead the prayer.

Hunting is discussed in literature as a male activity pertaining solely to killing an animal. Barbara Bodenhorn (I990: 55) states that this imposes patriarchal norms of men as dominant, controlling the public sphere, and of male activities as work. In contrast, she argues that hunting 'cannot be reduced to the catching and slaughtering of animals, but rather includes a whole set of activities ... in which the interdependence of men and women is fundamental' (ibid.). A hunt, for the Dene, includes preparation, travel, field dressing animals, returning to the community, distributing meat to female heads of households, preparation of the meat by these women, and serving the food. Sharing food necessarily involves the expertise of both genders, and is itself an integral aspect of hunting. Dene women are powerful hunters.

Including eating practices in my study reveals a patriarchal bias in other studies that focus on men's labour while ignoring that of women: the preparation, cooking, and distribution of the kill (see Pérez 20 I 4). Hultkrantz ( I 994: 357), for instance, discusses 'circumpolar animal ceremonialism' as the 'catching, killing, and burial of game'. While these are important parts of the Dene hunting paradigm, what happens to the animal in between killing and burial (returning remains to the land), notably the women's labour of preparing, cooking, and distributing food, is absent,.

Gendered labour is also fluid, allowing men and women to participate in each others' activities. Some women told me with pride that their fathers or husbands taught them to hunt and fish. Additionally, Dene women have an integral relationship with the hunted beyond gendered labour: women's actions at home or at a campsite are said to be taken into account by animals when deciding whether to give themselves (de Laguna and DeArmond I995: 60). Although gender inequality exists in Dene sociality, Dene women have important duties before, during, and after the receiving of an animal, the appropriate execution of which ensure that the animals will continue to give themselves.

Hunting is not a strictly male activity that happens apart from communal life, creating divisions within the community and between hunter and hunted; rather, it is the opposite. The activities of hunting necessarily draw connections with a larger community of human and other-than-human beings. The hunting goal of communal sustenance necessarily draws connections within the human 
community. Hunting, then, involves mutual sharing throughout in order for all to thrive. Thus, an appropriate response to a caribou decline within this social dynamic is better sharing.

\section{Returning food to the land}

Food exchanges within the human community and offerings to the animals, ancestors, and land are acts of respectful reciprocity that bind relationships. Dene elders told me that animals are aware when their meat is shared and honoured that their sacrifice is appreciated. Animals are also aware of what happens to their remains, which brings us to the final foodways stage: returning food to the land. The gift of the animal is returned in two manners, the first of which is returning food by-products so the animal may be reborn more easily. Bones, unused hide, and other remains are placed on the land for caribou and other land animals (Helm I 95 I: I 89), and in water for fish and other water animals (de Laguna and DeArmond 1995: 59-60), so that the animals may regenerate more easily when they are born again. Helping in this way is appreciated by the animal whose remains have been returned to the land. That gratitude is repaid

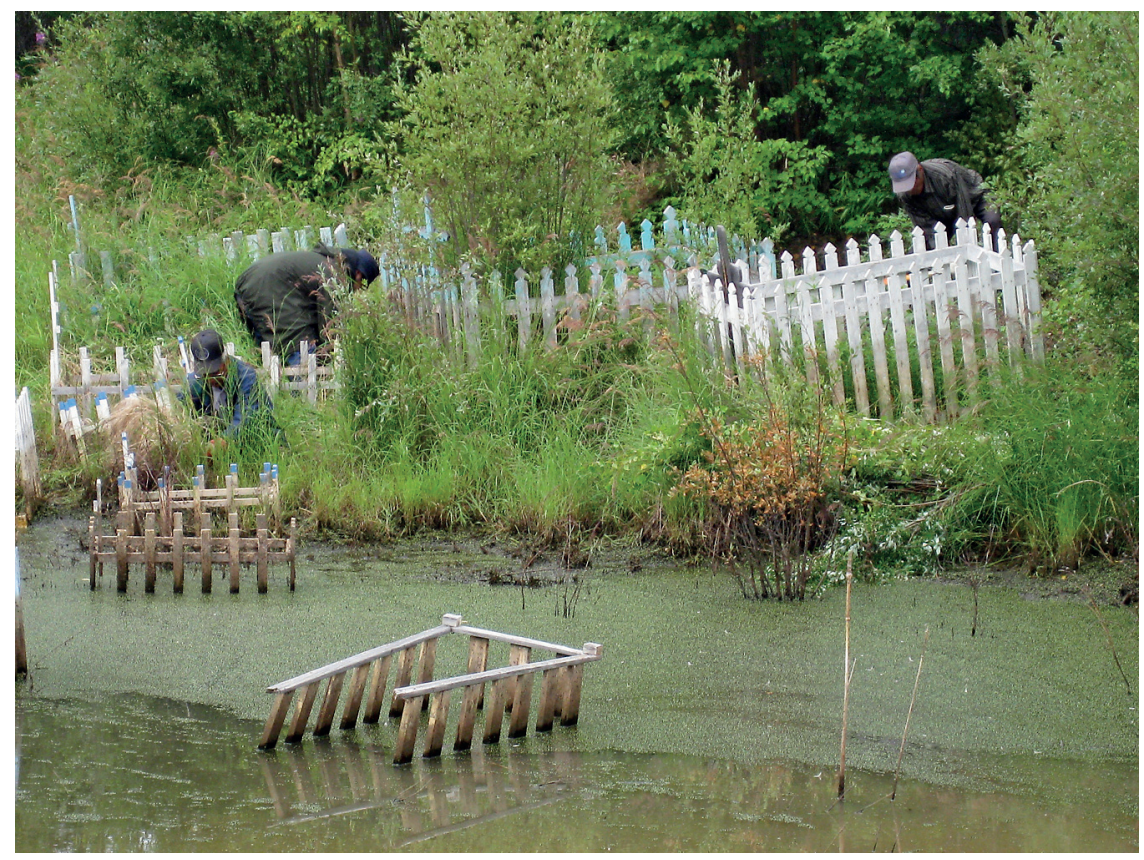

Individuals clearing grave sites for the ancestors, dọkw'ọọ whetọ̀, at a cemetery in the bush. Photograph by David S. Walsh. 
to the hunter as the animal is more likely to give itself again. In non-dualistic Dene ontologies, the human, animal, and ancestor persons converse in the same social world; offerings are not metaphorical but are real exchanges between persons expressed through social conventions of etiquette and gratitude.

The second manner of returning food to the land is through food offerings in ceremonies and personal acts of reciprocity called ghàts'èdi, 'to make an offering', or as my consultants state in English, to 'pay the land'. Dene tradition is to give ti ghàts'èedi when approaching a body of water, or de ghàts'èdi on an island or body of land they do not know (Zoe et al. 2009: I 2; see also Sharp 200I: 57). Offerings are accompanied with propitiations for safe travels and other aid, and are made to the water, land, and ancestors who have travelled there before. Or, as an elder explained to me, offerings are made to whomever may be listening. Legat (201 2: 83) states that paying the land maintains harmonious relations between the Dene and their environment. I witnessed the ill effects of not offering ghàts'èdi when a Tłich guide fell through the ice into the river below on a snowmobile trip with a group of non-native schoolteachers. The guide was fine and his machine was recovered; he had simply ridden over a spot of thin ice. But a Dene consultant later explained to me that one of the teachers must not have paid the river when we arrived in the area and that was why the accident happened, implying that the river swallowed the snowmobile as revenge for the slight. Ghàts'eèdi are not selfless acts, but are communication with the environment in which humans negotiate for what they need: safe travels and aid in hunting or medicine. It is a negotiation between getting what one wants, sustenance, and not upsetting the giver.

The Dene offer ghàts'èdi to ancestors through kì ghàts'èdi, or 'feeding the fire' (see Legat 2012: 92-5). Ancestors are deceased kin who continue to live on in the social world and in the domestic domain, and whom Miguel Astor-Aguilera states (2010: I64), 'one should take care of... so they assist when needed and do not bother when not needed'. Not all the deceased are ancestors, but the ones who remain in

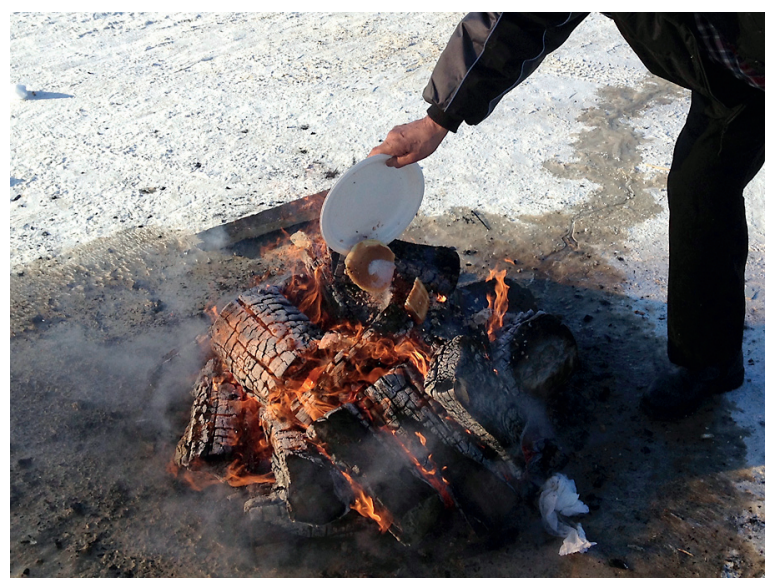

A Tłịchǫ individual performs kọ ghàts'eèdi - feeding the fire. Photograph by David S. Walsh. 
social relationships with the living, who can be engaged, in order to cajole, persuade, or indirectly manipulate on an inter relational basis... (as) similar to what humans do with one another in our daily social dramas' (ibid. I69) are the ancestors with whom the Dene may communicate.

While camping at an old settlement, an elder performed kò ghàts'è̀di at a cemetery located deep in the bush. The elder explained in English to myself and to the young people present that the ancestors buried there were very old, and we should each feed the fire with a small piece of traditional food that they miss in death and have been craving, such as caribou or fish. He added that there also might be children buried there who would appreciate a piece of candy. He then spoke words to the fire in Tłicho, the language the ancestors would understand, thanked the ancestors and the Creator and asked that they hear our requests while we each approached the fire and gave our offerings. The fire and offerings were not symbolic: the fire burned the food, transferring it into an edible state for the deceased, who retain their individual tastes in death.

Kò ghàts'èd $i$ allows for reciprocal exchange between personable beings. The ancestors are disadvantaged as they do not have the modern conveniences available to the living, and they need the living to feed them. The ancestors have power to aid the living not because they have received supernatural powers upon death, but because of the power they acquired while alive. Consultants, including the elder who performed the kò ghàts'èdi discussed above, stated that the Dene peoples had relied on relationships with other-than-human-beings to gain power in the world, before becoming dependent on modern conveniences. Recalling from the discussion above that Dene worldviews lack a Cartesian distinction between nature and culture, ancestors and other-than-human-beings are not separate from society, as may be articulated in a Western worldview: nature and the supernatural versus society. Instead, the living environment is where the Dene reside, but they have lost power in that environment while gaining the power of modern technologies. Modern Dene have an easier but less powerful life. Deceased kin maintain stronger connections with the environment than the living; yet it is the living who feed the ancestors.

The three foodways stages of getting, sharing, and giving back both allow for and are dependent on communication within a larger social body. Communication is possible because of a shared personhood between humans and non-human beings. Yet, while gifting draws humans and animals together, the reason for coming together is the desire for their difference. The purpose of respectful reciprocity is not to share in what hunter and hunted have in common, but to share in what they have independently that the other desires. The dynamic of give and take is a social one, mediated throughout the three 


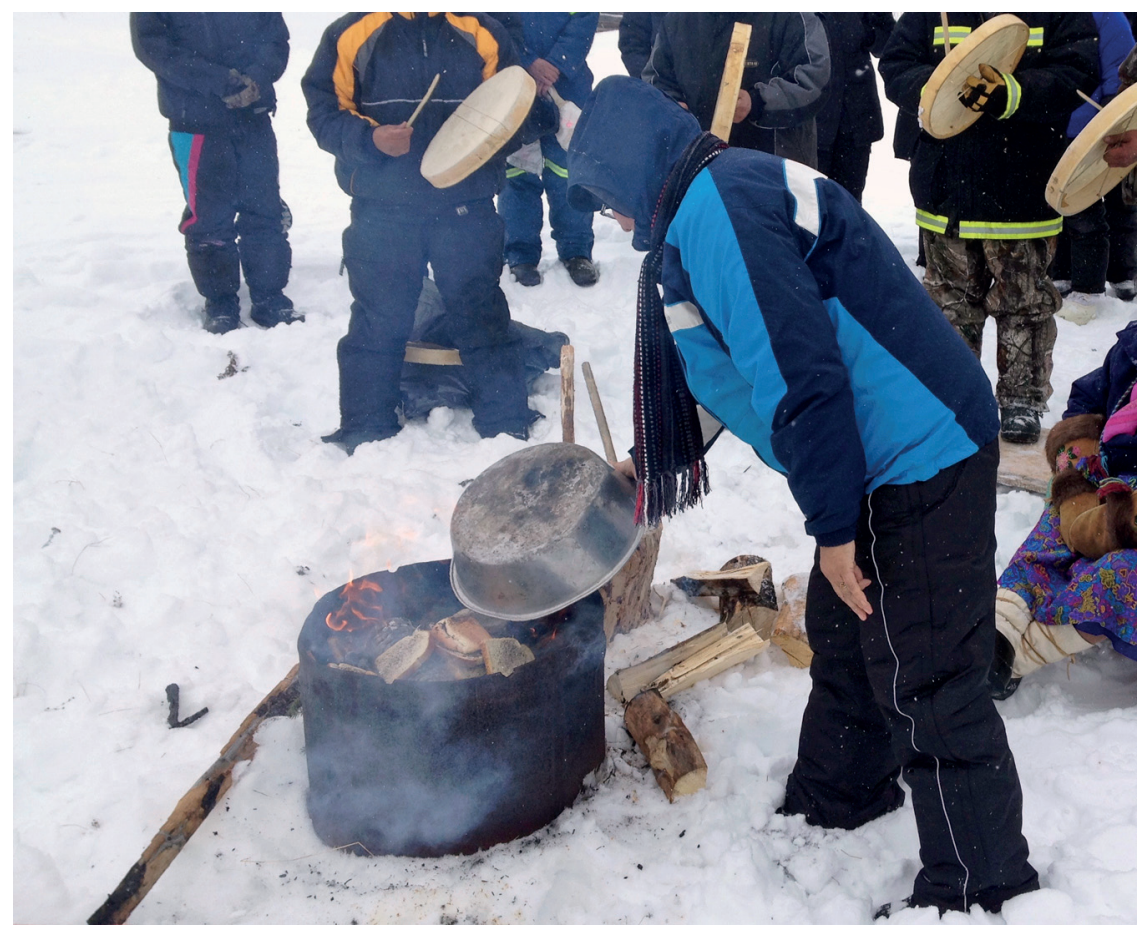

A woman pours bread and other foods into the fire at a kọ ghàts'eèdi ceremony. Photograph by David S. Walsh.

foodways stages. Reciprocity eases the tension of relying on the other for sustenance, and is refocused on in moments of crisis such as the current caribou population decline.

Conventions of etiquette toward animals, in modern contexts, operate predominantly at a discursive level for the Dene. Practices and proscriptions associated with animal regeneration, such as not giving caribou bones to dogs, or bringing the meat of another animal on a hunt, were discussed publicly by elders in response to the caribou hunting restrictions (Drybones and Walsh 20I I). The discussions reflect a strong sense of tradition about how to treat animals that the Dene can turn to in moments of crisis, when the relationship between hunter and hunted is under strain. While discourse and tradition remain strong, hunting is a matter of practical utility for the Dene, therefore conventions of etiquette need not always be followed. 


\section{Dene foodways in the era of climate change}

The decline of caribou herd populations in northern Canada at the turn of the century, and subsequent hunting restrictions of the Bathurst herd (see Adamczewski et al. 2009), has changed the relationship between the Dene and the caribou, and the Dene now rely more heavily on imported foods (Haman 20Io). Yet ontological assumptions about the nature of caribou have not changed, and they inform Dene responses to the current crises in relationship. Elders and other Dene with whom I have worked turn to tradition to offer solace and advice, and they express their tradition in innovative means through community workshops and public discussions (see Drybones and Walsh 20 I I). Dene foodways provide an arena for responses to climate change and caribou hunting restrictions. The foodways stages I delineate are best understood in the end, however, as an interrelated whole. As both the offering and the goal, food mediates exchanges between humans, ancestors, the land, and the animals. A successful hunt is an outcome of properly carrying out the latter stages. The hunt is dependent on properly sharing meat and on returning animal remains, and it may be aided by ancestors and the land.

Foodways, as a lens through which to examine indigenous relationships with the environment, reveal discourses used in order to receive what is needed. Moments of crisis reveal nuance to those discourses, strategies of survival that strike a balance between cajoling while not bothering the food animals. For instance, elders warned me not to speak too often of a caribou decline, for these words would upset the caribou whom were said to be listening (Drybones and Walsh 20I I). Theories of personhood, coupled with an examination through foodways, adds a materiality to the abstractions of spirituality, grounding my study in the relationships between the Tticho, the caribou, and other beings. Yet more importantly, Tticho Dene responses to crisis shed new light on previous studies of indigenous relationships, demonstrating that animals and ancestors are social beings with whom the Dene engage for the survival of their society. The Dene are connected to their past and history when making ghàts'èdi offerings to the ancestors, by asking the past to actively contribute to their sustenance today. To hunt caribou is to engage history and nourish a sense of self. Hunting restrictions cut the Tłichọ Dene off from their history, alienating them from a sense of Dene identity.

In contrast to Tylor's ( $187 \mathrm{I}: 427$ ) conception of animism as belief in souls and spirits abstracted from the environment, the Dene do not relate with animating spirits as separate entities. They engage with the actual, living, embodied agents who inhabit the environment: animals, plants, bodies of land and water, 
elements, rocks, and ancestors. June Helm (I 994: 70) states that the Ticho Denes' dreams and visions are experiences with 'the actual animal-being that is there and is speaking'. The Denes' environmental relationships, wherein humans can communicate with animal-beings are not predicated on belief, the defining feature of Tylor's (187I) animism. Belief in beings in the environment is of little consequence to the Dene, as those beings may affect one's life whether or not one believes in them. Respectful reciprocity maintains balance with these beings, therefore reciprocity is social and political. Human and animal relationships are fraught with power dynamics and negotiation, wherein respect is not 'awe' (see Otto I 958 [I9I7]), but is tied to propriety and etiquette to get what one needs: their flesh for sustenance. Respectful actions draw together hunters and the caribou, but caribou are desired for their difference. Climate change has strained Dene relationships with the caribou, but unlike Canadian strategies of wildlife management, Tłicho Dene elders have responded from the ontological assumption that the caribou must be approached respectfully, so the Tłicho can dine and the caribou will continue to thrive.

David Walsh has lived, worked, and shared in the foodways of the Tłicho, Dene in the Northwest Territories, Canada, since 2011. He has conducted ethnographic research on Dene ontologies, foodways, religion, and relationships with nature. David is completing his doctorate in Arizona State University's Religious Studies programme and is Assistant Professor of Religious Studies at Gettysburg College specializing in indigenous religions of the Americas.

\section{List of references}

Abel, Kerry, 2005. Drum Songs: Glimpses of Dene History (Montreal, McGill-Queen's University Press)

Adamczewski, Jan, John Boulanger, and Bruno Croft, 2009. 'Decline in the Bathurst caribou herd 2006-2009: A technical evaluation of field data and modeling' (Department of Environment and Natural Resources)

Andrews, Thomas D., 20 I I. 'There Will be Many Stories': Museum Antbropology, Collaboration, and the Tlicho, $\mathrm{PhD}$ dissertation, University of Dundee

Andrews, Thomas D., John B. Zoe, and Aaron Herter, r 998. 'On Yamòzhah's trail: Dogrib sacred sites and the anthropology of travel' in Sacred Lands: Aboriginal World Views, Claims, and Conflicts, ed. Jill Oakes, Rick Riewe, Kathi Kinew, and Elaine Maloney (Edmonton, Canadian Circumpolar Institute, University of Alberta), pp. 305-20

Astor-Aguilera, Miguel, 20 Io. The Maya World of Communicating Objects: Quadripartite Crosses, Trees, and Stones (Albuquerque, University of New Mexico Press)

Bell, Catherine, 1992. Ritual Theory, Ritual Practice (New York, Oxford University Press) 
Blondin, George, 2006. Trail of the Spirit: The Mysteries of Medicine Power Revealed (Edmonton, NeWest Press)

Bodenhorn, Barbara, I 990. "I'm not the great hunter, my wife is": Inupiat and anthropological models of gender', Etudes Inuit Studies, I 4( I-2), pp. 55-74

Crawford O’Brien, Suzanne, 20 I 4. 'Salmon as sacrament: first salmon ceremonies in the Pacific Northwest' in Religion, Food, and Eating in North America, ed. Benjamin E. Zeller, Marie W. Dallam, Reid L. Neilson, and Nora L. Rubel (New York, Columbia University Press), pp. I I 4-33

Descola, Philippe, 1996. In the Society of Nature: A Native Ecology in Amazonia (Cambridge University Press)

Detwiler, Fritz, I 992. 'All my relatives: persons in Oglala religion', Religion, 22(3), pp. $235-46$

Douglas, Mary, 1 966. Purity and Danger: An Analysis of Concepts of Pollution and Taboo (London, Routledge and Kegan Paul)

Drybones, Russell, and David Walsh, 2o I r. Tticho Traditional Caribou Conservation: Youth and Elders Working Together (Behchokò, Rae-Edzo Friendship Center)

Eden, Trudy, 2008. The Early American Table: Food and Society in the New World (DeKalb, Northern Illinois University Press)

Finch, Martha L., 20 Io. 'Food, taste, and American religions', Religion Compass, 4(I), pp. $39-50$

Fuller, R. C., I 996. Religion and Wine: A Cultural History of Wine Drinking in the United States (Knoxville, University of Tennessee Press)

Gill, Sam D., I982. Beyond the Primitive: The Religions of Nonliterate Peoples (New Jersey, Prentice-Hall)

Goulet, Jean-Guy A., I 998. Ways of Knowing: Experience, Knowledge, and Power Among the Dene Tha (Vancouver, University of British Columbia Press)

Grim, John A., 200 r. 'Introduction' in Indigenous Traditions and Ecology, ed. John A. Grim (Cambridge, Harvard Divinity School, Center for the Study of World Religions), pp. XXIII-LVII

GuDistr Marie-Francois, r 994. 'Dene ways and the ethnographer e-culture' in Being Changed: The Anthropology of Extraordinary Experience, ed. Jean Guy Goulet and D. E. Young (Peterbrough, Broadview Press), pp. 39-70

Gunn, Anne, 2007. 'The position of caribou in the north: an overview', Northern Perspectives, $3 \mathrm{I}(\mathrm{I})$, pp. 3-5

Hallowell, A. Irving, 1967 [ 1 955]. Culture and Experience (New York, Schocken Books)

— 1975 [ I 960]. 'Ojibwa ontology, behavior, and world view' in Teachings from the American Earth: Indian Religion and Philosophy, ed. Dennis Tedlock and Barbara Tedlock (New York, Liveright), pp. I 4 I-78

Haman, François, 2010. 'Obesity and type 2 diabetes in northern Canada's remote First Nations communities: the dietary dilemma', International Journal of Obesity $34\left(\mathrm{~S}_{2}\right)$, pp. 24-3 I

Harris, Patricia, David Lyon, and Sue McLaughlin, 2005. The Meaning of Food (Guilford, The Globe and Pequot Press) 
Harvey, Graham, 2005. Animism: Respecting the Living World (London, Hurst and Company)

2010. 'Animism rather than shamanism: new approaches to what shamans do (for other animists)' in Spirit Possession and Trance, ed. Bettina Schmidt and Lucy Huskinson (London, Continuum), pp. I4-34

Helm, June, r 95 r. 'Contemporary folk beliefs of a slave Indian band', The Journal of American Folklore, 67(264), pp. I 85-98

- i 994. Prophecy and Power Among the Dogrib Indians (Lincoln, University of Nebraska Press)

-2000. The People of Denendeh: Ethnohistory of the Indians of Canada's Northwest (Iowa, University of Iowa Press)

Helm, June, and Beryl C. Gillespie, I 98 r. 'Dogrib oral tradition as history: war and peace in the I 82 os', Journal of Anthropological Research, 37(I), pp. 8-27

Holst, Wayne A., I 997. 'Aboriginal spirituality and environmental respect: a perspective on traditional Amerindian views of nature with special reference to the meaning of "the land" in northern cultures', Social Compass, $44(\mathrm{I})$, pp. $145-56$

Hultkrantz, Åke, I 994. 'Religion and environment among the Saami: an ecological study' in Circumpolar Religion and Ecology: An Anthropology of the North, ed. Takashi Irimoto and Takako Yamada (University of Tokyo Press), pp. 347-74

Ingold, Tim, 2000. The Perception of the Environment: Essays on Livelihood, Dwelling and Skill (London, Routledge)

Jacobsen, Petter, 20 I I. 'With a Connection to the Land, Our Spirit is Strong' Tlicho Traditional Knowledge of Climate Change and Impacts for Caribou Hunting: Implications for Traditional Knowledge Research, MA thesis, University of Northern British Columbia

Laguna, Frederica de, and Dale DeArmond, 1995. Tales From the Dena: Indian Stories From the Tanana, Koyukuk and Yukon Rivers (Seattle, University of Washington Press)

Latour, Bruno, 1993. We Have Never Been Modern (Cambridge, Harvard University Press)

Legat, Allice, 20 I 2. Walking the Land, Feeding the Fire: Knowledge and Stewardship Among the Tlicho Dene (Tuscan, University of Arizona Press)

Long, Lucy M., 2004. 'Introduction' in Culinary Tourism, ed. Lucy M. Long (Lexington, University Press of Kentucky), pp. I-I 9

Madden, Etta M., and Martha L. Finch, 2006. 'Introduction' in Eden: Food and American Utopias, ed. Etta M. Madden and Martha L. Finch Eating (Lincoln, University of Nebraska Press), pp. I-3 I

Mason, John Alden, I 9 I4. 'On work among northern Athabaskan tribes, I 9 I 3: summary report' in Geological Survey of Canada, Sessional Paper No. 26 (Canada)

Morrison, Kenneth M., 2002. The Solidarity of Kin: Ethnohistory, Religious Studies, and the Algonkain-French Religious Encounter (Albany, State University of New York Press) 
Nabokov, Peter, 2007. Where the Lightning Strikes: The Lives of American Indian Sacred Places (New York, Penguin)

Nadasdy, Paul, 2003. Hunters and Bureaucrats: Power, Knowledge, and Aboriginal-State Relations in the Southwest Yukon (Vancouver, UBC Press)

_-20I I. "We don't harvest animals; we kill them”: agricultural metaphors and the politics of wildlife management in the Yukon' in Knowing Nature: Conversations at the Intersection of Political Ecology and Science Studies, ed. Mara Goldman, Paul Nadasdy, and Matthew D. Turner (University of Chicago Press), pp. I35-5 I

Nelson, Richard K., I 983. Make Prayers to the Raven: A Koyukon View of the Northern Forest (University of Chicago Press)

NWT, Bureau of Statistics, 2013. Populations Estimates as at July ist, by Community, Northwest Territories, 20I I-20I3.

Olson, Carl, 20 I I. Religious Studies: The Key Concepts (London, Routledge)

Otto, Rudolf, 1958 [1917]. The Idea of the Holy: An Inquiry into the Non-rational Factor in the Idea of the Divine and its Relation to the Rational (London, Oxford University Press)

Pérez, Elizabeth, 20 I4. 'Crystallizing subjectivities in African diaspora: sugar, honey, and gods of Afro-Cuban Lucumí' in Religion, Food, and Eating in North America, ed. Benjamin E. Zeller, Marie W. Dallam, Reid L. Neilson, and Nora L. Rubel (New York, Columbia University Press), pp. I 75-94

Petitot, Emile, 2005. Travels Around Great Slave and Great Bear Lakes, 1862-1882 (Toronto, Champlain Society)

Ridington, Robin, 1990. Little Bit Know Something: Stories in a Language of Anthropology (Iowa, University of Iowa Press)

Ryan, Joan, 1995. Doing Things the Right Way: Dene Traditional Justice in Lac La Martre (University of Calgary Press)

Sack, Daniel, 200o. Whitebread Protestants: Food and Religion in American Culture (New York, St. Marin's Press)

Sharp, Henry S., 200 I. Loon: Memory, Meaning, and Reality in a Northern Dene Community (Lincoln, University of Nebraska Press)

Shorter, David Delgado, 2009. We Will Dance Our Trutb: Yaqui History in Yoeme Performances (Lincoln, University of Nebraska Press)

Simeone, William E., I 995. Rifles, Blankets, and Beads: Identity, History, and the Northern Athapaskan Potlatch (Norman, University of Oklahoma Press)

Smith, David M., r 998. 'An Athapaskan way of knowing: Chipewyan ontology', American Ethnologist, 25(3), pp. 4I 2-32

2002. 'The flesh and the word: stories and other gifts of the animals in Chipewyan cosmology', Antbropology and Humanism, 27(I), pp. 6o-79

Swanson, Tod D., 2009. 'Singing to estranged lovers: Runa relations to plants in the Ecuadorian Amazon', Journal for the Study of Religion, Nature and Culture, 3(I), pp. 36-65 
Tłichǫ Government, 2005. Tticho Constitution (Behchokò)

20 I 2. 'Iłe de gha goita... In Tlicho Unity..., A Strategic Framerwork and Intentions 2009 to 2013 for the Tticho Government (Behchokò)

Tylor, Edward B., I87 I. Primitive Culture: Researches into the Development of Mythology, Philosophy, Religion, Language, Art, and Custom (London, John Murray)

Viveiros de Castro, Eduardo, I 998. 'Cosmological deixis and Amerindian perspectivism', Journal of the Royal Anthropological Institute, 4(3), pp. 469-88

Walsh, David, 2or r. 'Moving beyond Widdowson and Howard: traditional knowledge as an approach to knowledge', International Journal of Critical Indigenous Studies, 4(I), pp. 2-I I

Zeller, Benjamin E., Marie W. Dallam, Reid L. Neilson, and Nora L. Rubel, 20 I 4. Religion, Food, and Eating in North America (New York, Columbia University Press)

Zoe, Therese, Philip Zoe, and Mindy Willet, 2009. Living Stories: Godi Weghàà Ets'è̀da (Markham, Fifth House Ltd.) 